\title{
Behavioural and physiological characteristics of standard and chromosomally divergent populations of house mice from the Orkney archipelago (Scotland)
}

\author{
Guila GANEM
}

Ganem G. 1998. Behavioural and physiological characteristics of standard and chromosomally divergent populations of house mice from the Orkney archipelago (Scotland). Acta Theriologica 43: 23-38.

House mice Mus musculus domesticus (Schwartz and Schwartz, 1943) from Orkney are closely related on the basis of mandible morphology and allozyme variation. In three of the twenty islands where house mice occur populations have diverged from the standard $2 \mathrm{n}=40$ karyotype through fixation of Robertsonian $(\mathrm{Rb})$ chromosomal mutations. Mice from Westray island carry 36 chromosomes and share one Rb fusion with those from Eday and Faray $(2 n=34 ; 2 n=34-36)$. These islands are geographically very close to each other and to islands carrying standard mice. Behavioural and ecophysiological analyses were performed on the three chromosomally divergent populations of mice as well as on two nearby standard populations (Sanday and Papa-Westray). The aim of the study was to assess whether divergences attributable to chromosomal changes occur, and to discuss whether behavioural divergences may explain the non-mixing of karyotypes. The study does not reveal any divergence between islands attributable to karyotype or habitat differences. The non-blending of the different karyotypes present in Orkney is discussed with reference to history of colonisation, human behaviour, and the consequences of site saturation. Particular characteristics displayed by the different island-populations suggest that in the near future the present pattern of karyotype variation observed in Orkney could change.

Laboratory Génétique et Environnement, Institut des Sciences de l'Evolution, UMR 5554 University Montpellier II, Pl. E. Bataillon, C.C. 065, 34095 Montpellier cedex 5, France; fax: 33/ (0)467143622, e-mail: gganem@isem.univ-montp2.fr

Key words: Mus musculus, islands, commensalism, dyadic encounters, corticosterone

\section{Introduction}

Chromosomal evolution corresponds to divergence within a species by means of mutation events affecting chromosomes. Such differentiation occurs among house mice Mus musculus domesticus (Schwartz and Schwartz, 1943) (standard karyotype $2 \mathrm{n}=40$ ), and involves the accumulation of chromosomal mutations which consist of a fusion between two acrocentric chromosomes resulting in a metacentric (Robertsonian mutation). Populations of mice carrying up to nine different fusions $(2 \mathrm{n}=39$ to $2 \mathrm{n}=22)$ have been described in Europe and Tunisia (Bauchau 1990), and the phenomenon is thought to have started less than 10,000 years ago (Auffray 1993, Nachman et al. 1994). 
Orkney archipelago consists of a central large island surrounded by approximately 100 islands. House mice occur in 20 islands of the archipelago, and Robertsonian populations of mice occur on 3 of them (Westray, Eday, Faray; Fig. 1) (Adolph and Klein 1981).

Different karyotypes characterise the 3 Robertsonian populations of Orkney. The fusion between chromosomes 9 and 12 is shared by the 3 islands, suggesting a common ancestor. Fusion 3.14 occurs in Eday and Faray but not in Westray where chromosome 14 is involved in a fusion with chromosome 6 . Fusion 4.10 occurs in Eday $(2 \mathrm{n}=34)$, segregates in Faray but do not occur in Westray $(2 \mathrm{n}=36)$.

Orkney mice are related to mice in Caithness (north-eastern Scotland) and are believed to have a common origin different from mice of southern Britain (Nash et al. 1983). Moreover, two of Orkney fusions (9.12 and 4.10) are widespread in Caithness (Searle et al. 1993). Anthropology of these regions reveals that the inhabitants are of Norse descent and most of the trade was with Scandinavia. The earliest link likely to have introduced mice to the islands was in $600 \mathrm{AD}$ (Nash et al. 1983). Nowadays these islands are described as "agricultural undulations" (Berry 1985) very favourable to the house mouse.

Despite chromosomal variation, populations of mice in Orkney are closely related on the basis of mandible morphology and biochemical traits (Davis 1983, Nash et al. 1983). However the protein polymorphism suggests little or no gene flow between Orkney islands over a considerable time period (Nash et al. 1983).

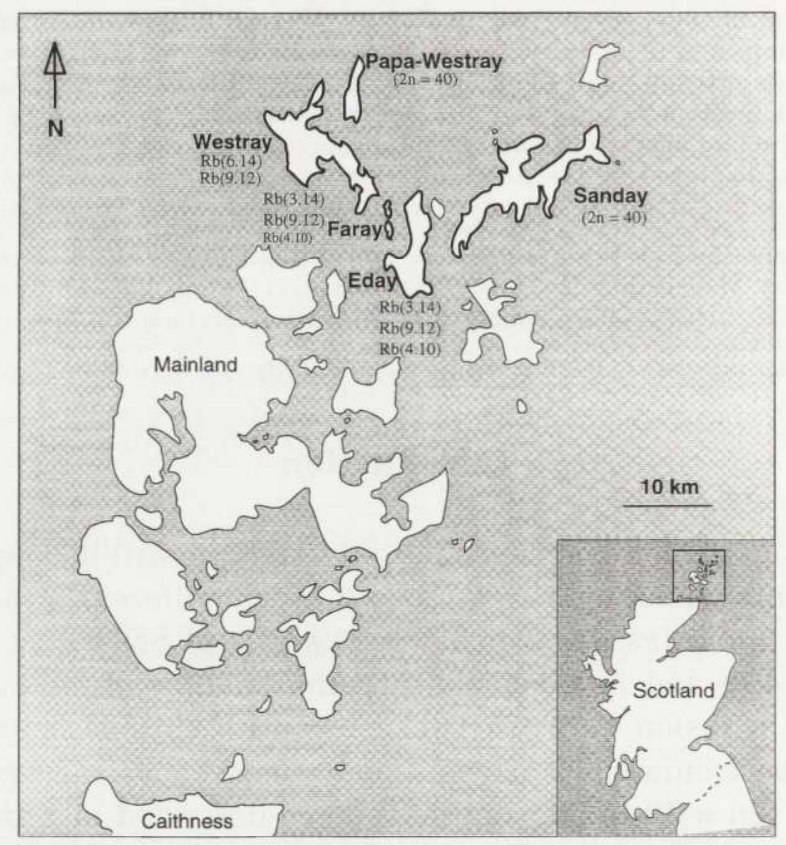

Fig. 1. Geographical situation of the Orkney archipelago. Karyotype of mice in islands involved in the study are specified. 
This fact is surprising as it indicates that although boat traffic between the islands could facilitate passive transport of mice, immigration is not effective.

The purpose of the study reported here was to detect whether isolation between the islands resulted in behavioural and ecophysiological divergence between the different chromosomal types and whether local adaptations may explain the non-mixing of karyotypes between islands. Behavioural investigations were aimed to analyse between-individual interactions within each island (Ganem and Searle 1996a) and document possible differences in social structures. Reaction to spatial novelty was also compared using a open-field test, commonly used for the assessment of rodent emotivity (Candland and Nagy 1969).

Corticosterone is a useful index of emotional arousal in rodents, and in mice particularly (Pfister 1979, Schuhr 1987, Genetsch et al. 1988, Ganem and Searle 1996b), and emotivity can serve as an index of adaptation to commensalism (Ganem 1991). Thus, corticosterone was used as an index to compare the different chromosomal types. The hormone was assayed in blood samples collected at the end of the different behavioural tests and in standardised conditions. Additionally, observations made in the field, and measures of reproductive organs after sacrifice, complete this study and allow to compare aspects of the fertility of populations of mice in the different islands (Pelikan 1981).

\section{Material and methods}

\section{Animals}

The Orkney archipelago lies between $58^{\circ} 41^{\prime} \mathrm{N}$ and $59^{\circ} 24^{\prime} \mathrm{N}$ latitude and $2^{\circ} 22^{\prime} \mathrm{W}$ and $4^{\circ} 25^{\prime} \mathrm{W}$ longitude. Four islands of the archipelago were sampled by myself: Westray $(2 n=36)$, Eday $(2 n=34)$, Faray $(2 n=34-36)$ and Papa-Westray $(2 n=40)$. A sample of mice from Sanday $(2 n=40)$ was kindly collected by an inhabitant. All the islands are inhabited by man except Faray which has been uninhabited since 1947. The island is now used as sheep pasture by farmers from Westray who stay on the island only during the lambing season.

The first field session lasted two weeks (end of March to beginning of April 1992). Populations of two islands, Westray and Eday, were trapped in different farms using Longworth live-traps, and collected by hand during the threshing of cereal ricks. In Papa-Westray and Sanday trapping was unsuccessful, therefore, mice were caught only by hand, during the threshing of cereal ricks.

During the second field session (end of August 1992) mice were trapped in Eday and Faray. In Eday mice were trapped in the same sites as at the first session. Intensive trapping in moorlands and agricultural fields of Eday resulted in trapping of Apodemus sylvaticus but no Mus musculus domesticus. The few commensal habitats available on Faray were found to be empty of mice (intensive poisoning for several years, M. Hewison pers. comm.) and house mice were only successfully trapped outdoors, along the sea shore. Mice obtained during the second field session allow a comparison between Robertsonian populations occurring in different habitats: outdoor (Faray) and commensal (Eday).

Weight, sex and general condition were noted at capture. Population size is expressed, when possible, as the number of mice/100 trap-nights, and sex ratio (S-R) is described in terms of total number of males/total number of females. The reproductive condition of females is indicated by an index calculated as the ratio of the number of pregnant and lactating females/total number of adult females. 


\section{Behavioural tests}

All the behavioural tests took place between $18.00-20.00$, in a room separated from the animal house. Adult mice from the same population were maintained in male-female pairs under standard laboratory conditions (light between 8.00-20.00) for 6 weeks before the start of the behavioural experiments. Acclimatisation was aimed at eliminating trapping, transport, and housing effects. In order to eliminate interactive effects due to the reproductive state of the females (examined externally and by vaginal smear), oestrus, pregnant and lactating mice were excluded from the experiments.

First, the animals were subjected to an open-field test. Each mouse was allowed 10 minutes in a neutral arena $(80 \times 30 \times 30 \mathrm{~cm})$, and its behaviour recorded. Three elements of behaviour were distinguished: (1) vertical and horizontal movements while the mice explore the arena, (2) immobility and (3) grooming. The first item was categorised as non-social active behaviour, the two other items were pooled under the category of non-social passive behaviour. The total period during which each individual was engaged in each category of behaviour was calculated as the number of intervals of one minute in which a category of behaviour was observed at least once. When the two categories were observed at the same interval, each was assigned 0.5. An index of non-social active behaviour (Ia) was calculated. Non-social passive behaviour (Ip) was obtained by subtracting Ia from 1 . The open-field test concerned 92 mice from the 4 islands sampled at the first field session, and 20 mice from the 2 islands sampled at the second field session (same number of males and females in each sample).

A few days later the same mice and others were involved in dyadic encounters, intra-sex then inter-sex. All mice, returned to their original pair, were rested 3 days between each test. The encounters were performed in the above described neutral arena separated into two compartments. Each mouse was removed from its cage and placed in one of the compartments. After a few seconds, the partition was raised and the test begun. Each encounter lasted 10 minutes during which several elements of social behaviour, and of behaviour not implying interactions between individuals, were recorded. These elements were ordered into behavioural categories routinely used for studies of laboratory and wild mice (Mackintosh 1981, Hurst 1993): Si - social investigative behaviour: a series of relational behaviours not followed by aggression, such as approach (movement towards the opponent not followed by aggression), nose (sniffing the tip of the snout), sniff (sniffing any part of the body), investigate, follow; Sg - gregariousness: immobile touching the opponent; Sd - social defensive behaviour: defensive postures, flee; Sa - social aggressive behaviour: approach and investigation followed by aggression, aggressive postures, attack and chase; Sav - social avoidance behaviour: direct interaction with the opponent avoided from a distance; nSa - non-social active behaviour: exploration of the apparatus; nSp - non-social passive behaviour: maintenance activity, and immobility. The frequency with which each individual was engaged in each category of behaviour was calculated as the number of intervals of one minute in which a category of behaviour was observed at least once. The behaviour of each mouse in a dyad was recorded separately. The within-sex encounters concerned 88 mice from the 4 islands sampled at the first field session. The between-sex encounters concerned 52 mice from the 4 islands sampled at the first session and 20 mice from the 2 islands sampled at the second session (see Tables $2 \mathrm{~b}$ and 3 ).

\section{Physiology}

Plasma corticosterone was assayed in blood samples taken from the retro-orbital sinus of the mouse within 3 minutes of handling. The first sampling took place two weeks before the start of the behavioural experiments to obtain reference levels, then every behavioural test was followed by a blood sampling to assess the physiological impact of those tests. Animals were sacrificed at the end of the experiments, weighed and measured. Testis, seminal vesicles and adrenal glands were kept in formalin for weighing. 


\section{Data analysis}

In order to compare behaviour during dyadic encounters, the behaviour of the 2 individuals was recorded separately, and a correlation test was applied on members of dyads assigned randomly to position 1 or 2 (Kendall test for correlation). An absence of a statistical correlation meant that the approximation that the 2 members of a dyad were independent observations, a necessary condition for the use of an analysis of variance, could be accepted. The 7 behavioural categories recorded during the pairwise encounters were split into 2 series in order to reduce dependence between measures. The first series includes 3 behavioural items ( $\mathrm{nSa}, \mathrm{nSp}, \mathrm{Sg}$ ) and the second series comprises 4 behavioural categories ( $\mathrm{Si}, \mathrm{Sa}, \mathrm{Sd}$, Sav). Wilks' likelihood ratio was chosen as the test statistic for a multivariate analysis of variance (Abacus Concepts, Super ANOVA, Gagnon et al. 1989). Normality and non-correlation between behavioural categories were also checked for. When necessary 2 and 3-way ANOVA were performed. In order to avoid assumptions on normality of subsamples, as well as bias associated to their small and unequal size the Scheffé's statistic was used for post-hoc multiple comparison of means (Scheffé 1959; Abacus Concept, Super-ANOVA). Hormone concentrations required $\log$ transformation for normalisation before being analysed. When the same mouse was subjected to the different experiments a repeated 2-way ANOVA was applied on the hormonal data but did not reveal any significant repetition effect (no within individual variations: GG epsilon $=1$, H-F epsilon $=1.1$ ). Thus these data were pooled with the others, and levels of corticosterone were compared within the entire sample using a simple 2-way ANOVA.

\section{Results}

\section{Demography}

All populations were found to be reproductively active. At the same season, population size was 3 times higher in Westray than in Eday, and higher in the outdoor habitat of Faray than in the commensal habitat of Eday. On average, females were found to be in excess of males on all the islands: $S-R=0.74 \pm 0.05$ (comparison to 1, Student test: $\mathrm{df}=5, T=-5.08, p=0.004$; Fig. 2).

\section{Behaviour}

The two standard populations display variable behaviour in open-field conditions. Mice from Sanday display the lowest frequency of active behaviour while mice from Papa-Westray display the highest frequency (Table 1).

Behavioural differences between the 4 islands during dyadic encounters were tested using a two factor MANOVA. Considering the first series of behavioural categories: non-social active and passive behaviours and gregariousness, the different islands present significant differences due to Westray mice displaying less non-social active behaviour than mice from the 3 other islands (Table 2a, c, d). Moreover, Westray and Papa-Westray present similar levels of non-social passive behaviour, which is lower than in Eday and Sanday.

The analysis of the second series of behavioural categories, social investigation, aggression, defence and avoidance, reveals significant main and interactive island effects (Table 2). Papa-Westray mice are distinguishable from mice from the other 3 islands by a higher frequency of social investigative behaviour, and from Sanday and Westray mice by a lower frequency of avoidance (Table 2c, d). Interaction 


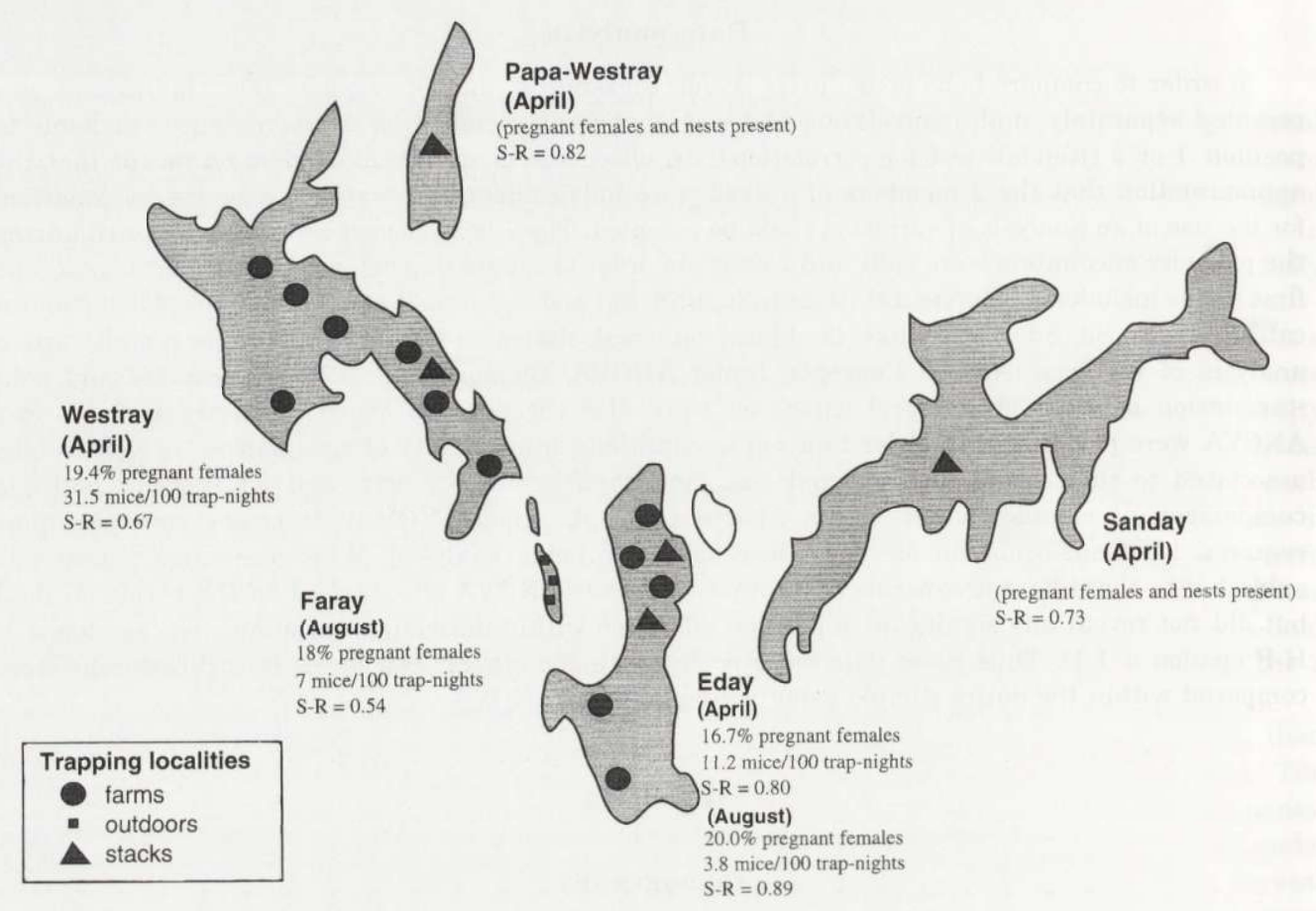

Fig. 2. Distribution of trapping localities on the 5 islands of the Orkney archipelago and summary of some of the population characteristics.

Table 1. Index of non-social active behaviour (Ia) displayed by mice during a 10 -minute period in a neutral arena (open-field). The index is expressed as the ratio between duration of the behaviour display and total duration of the experiment (mean $\pm \mathrm{SE}$ ). 2-way ANOVA: island effect, $F_{3,84}=19.03, p=0.001$ (post-hoc multiple comparison of means: Sanday/Westray, $p=0.0001$; Sanday/Papa-Westray, $p=0.0001$; Sanday/Eday, $p=0.001$; Eday/Papa-Westray, $p=0.002$ ); sex effect, $F_{1,84}=0.44, p>0.05$; islands $\times \operatorname{sex}, F_{3,84}=2.51$, $p>0.05$.

\begin{tabular}{lcc}
\hline Islands & Number of individuals & Ia \\
\hline Westray & 20 & $0.57 \pm 0.05$ \\
Eday & 32 & $0.50 \pm 0.04$ \\
Papa-Westray & 20 & $0.75 \pm 0.04$ \\
Sanday & 20 & $0.23 \pm 0.06$ \\
\hline
\end{tabular}

between island and sex concerns only aggressive behaviour. Males from Sanday are distinguishable because they display more frequent aggressive behaviour during inter-sex encounters compared to males from the 3 other islands (Table $2 \mathrm{a}$, b; contrast test: $\mathrm{df}=1, F=13.46, p=0.0004$ ). 
Table 2. Bahavioural display during within-population dyadic encounters in house mice from the Orkney archipelago. See p. 26 for explanation of the symbols of behavioural categories.

(a) Summary of the two MANOVA analyses on 3 behavioural categories ( $\mathrm{nSa}, \mathrm{nSp}, \mathrm{Sg}$ ) in the first series and 4 behavioural categories ( $\mathrm{Si}, \mathrm{Sa}, \mathrm{Sd}, \mathrm{Sav})$ in the second series. Only significant effects are given. Sex is considered as nested in type encounter: intra- or inter-sex.

\begin{tabular}{lcll}
\hline Factors & Wilk's statistic & \multicolumn{1}{c}{$p$} & Behavioural category \\
\hline $\begin{array}{l}\text { First series } \\
\quad \text { Population }\end{array}$ & 0.57 & 0.0001 & $\mathrm{nSa}, \mathrm{nSp}, \mathrm{Sg}$ \\
$\begin{array}{l}\text { Type of encounter (sex) } \\
\text { Population } \times \text { type (sex) }\end{array}$ & 0.74 & 0.0001 & $\mathrm{nSa}$ \\
$\begin{array}{l}\text { Second series } \\
\quad \text { Population }\end{array}$ & 0.82 & 0.57 & $\mathrm{none}$ \\
$\begin{array}{l}\text { Type of encounter (sex) } \\
\text { Population } \times \text { type (sex) }\end{array}$ & 0.88 & 0.0001 & $\mathrm{Si}, \mathrm{Sa}, \mathrm{Sd}, \mathrm{Sav}$ \\
& 0.63 & 0.17 & none \\
\hline
\end{tabular}

(b) Statistical significance of multiple comparisons between islands (Scheffé's test, the $p$ are in bold when $<0.05$ ).

\begin{tabular}{lccccccc}
\hline \multirow{2}{*}{ Islands } & \multicolumn{7}{c}{ Behavioural category } \\
\cline { 2 - 8 } & $\mathrm{nSa}$ & $\mathrm{nSp}$ & $\mathrm{Sg}$ & $\mathrm{Si}$ & $\mathrm{Sa}$ & $\mathrm{Sd}$ & $\mathrm{Sav}$ \\
\hline Westray/Eday & $\mathbf{0 . 0 0 5}$ & $\mathbf{0 . 0 0 7}$ & 0.886 & 0.673 & 0.455 & 0.193 & 0.436 \\
Westray/Sanday & $\mathbf{0 . 0 0 1}$ & $\mathbf{0 . 0 1}$ & 0.832 & 0.870 & 0.999 & 0.965 & 0.981 \\
Westray/Papa-Westray & $\mathbf{0 . 0 0 0}$ & 0.999 & 0.460 & $\mathbf{0 . 0 0 0}$ & 0.840 & 0.058 & $\mathbf{0 . 0 1 1}$ \\
Eday/Sanday & 0.828 & 0.998 & 0.997 & 0.990 & 0.305 & 0.387 & 0.656 \\
Eday/Papa-Westray & 0.569 & $\mathbf{0 . 0 0 6}$ & 0.064 & $\mathbf{0 . 0 0 0}$ & 0.945 & 0.847 & 0.174 \\
Sanday/Papa-Westray & 0.975 & $\mathbf{0 . 0 0 6}$ & 0.071 & $\mathbf{0 . 0 0 0}$ & 0.743 & 0.140 & $\mathbf{0 . 0 2 2}$ \\
\hline
\end{tabular}

(c) Frequency of occurrence (mean $\pm \mathrm{SE}$ ) of aggressive behaviour (Sa). $n$ - number of individuals.

\begin{tabular}{|c|c|c|c|c|c|c|}
\hline \multirow{2}{*}{ Islands } & \multicolumn{3}{|c|}{ Intra-sex } & \multicolumn{3}{|c|}{ Inter-sex } \\
\hline & $n$ & Males & Females & $n$ & Males & Females \\
\hline Westray & 8 & $1.0 \pm 0.6$ & $0.9 \pm 0.6$ & 5 & $1.0 \pm 0.8$ & $2.6 \pm 1.5$ \\
\hline Eday & 16 & $1.6 \pm 0.7$ & $0.2 \pm 0.1$ & 10 & $0.2 \pm 0.2$ & $0.0 \pm 0.0$ \\
\hline Papa-Westray & 10 & $1.4 \pm 0.4$ & $0.0 \pm 0.0$ & 5 & $1.0 \pm 0.4$ & $1.2 \pm 0.7$ \\
\hline Sanday & 10 & $0.8 \pm 0.3$ & $0.6 \pm 0.4$ & 6 & $3.7 \pm 1.4$ & $1.2 \pm 0.4$ \\
\hline
\end{tabular}

(d) Frequency of occurrence (mean $\pm \mathrm{SE}$ ) of the 6 other behavioural categories.

\begin{tabular}{|c|c|c|c|c|c|c|c|}
\hline \multirow{2}{*}{ Islands } & \multirow{2}{*}{$n$} & \multicolumn{6}{|c|}{ Behavioural category } \\
\hline & & $\mathrm{nSa}$ & $\mathrm{nSp}$ & $\mathrm{Sg}$ & $\mathrm{Si}$ & $\mathrm{Sd}$ & Sav \\
\hline Westray & 26 & $4.5 \pm 0.5$ & $4.7 \pm 0.3$ & $1.2 \pm 0.4$ & $3.7 \pm 0.5$ & $1.8 \pm 0.5$ & $1.2 \pm 0.3$ \\
\hline Eday & 52 & $6.3 \pm 0.3$ & $6.5 \pm 0.3$ & $0.9 \pm 0.2$ & $4.4 \pm 0.3$ & $0.8 \pm 0.2$ & $0.7 \pm 0.1$ \\
\hline Papa-Westray & 30 & $7.0 \pm 0.4$ & $4.8 \pm 0.4$ & $0.8 \pm 0.2$ & $7.0 \pm 0.4$ & $1.6 \pm 0.4$ & $0.1 \pm 0.1$ \\
\hline Sanday & 32 & $6.7 \pm 0.4$ & $6.6 \pm 0.3$ & $1.8 \pm 0.3$ & $4.2 \pm 0.4$ & $0.4 \pm 0.1$ & $1.1 \pm 0.2$ \\
\hline
\end{tabular}


Table 3. Frequency (mean $\pm \mathrm{SE}$ ) of behavioural display during inter-sex dyadic encounters of mice from two islands of the Orkney archipelago trapped in August 1992. MANOVA on variables $\mathrm{nSa}, \mathrm{nSp}$, and Sg: island, Wilks' statistics $(\mathrm{Ws})=0.93, p=0.8$; sex, Ws $=0.75, p=0.25$; island $\times$ sex, Ws $=0.79$, $p=0.3$. MANOVA on variables $\mathrm{Si}, \mathrm{Sa}, \mathrm{Sd}$, and Sav: island, Ws $=0.96, p=1.0 ; \mathrm{sex}, \mathrm{Ws}=0.50, p=$ 0.045 ; island $\times \operatorname{sex}, \mathrm{Ws}=0.85, p=0.7$. See $\mathrm{p}$. 26 for explanation of the behavioural category symbols.

\begin{tabular}{|c|c|c|c|c|c|c|c|c|}
\hline \multirow{2}{*}{ Islands } & \multirow{2}{*}{$n$} & \multicolumn{7}{|c|}{ Behavioural category } \\
\hline & & $\mathrm{nSa}$ & $\mathrm{nSp}$ & $\mathrm{Sg}$ & $\mathrm{Si}$ & $\mathrm{Sa}$ & $\mathrm{Sd}$ & Sav \\
\hline Eday & 10 & $8.0 \pm 0.5$ & $6.9 \pm 0.5$ & $1.2 \pm 0.4$ & $4.5 \pm 0.4$ & $0.6 \pm 0.4$ & $1.7 \pm 0.8$ & $1.6 \pm 0.7$ \\
\hline Faray & 10 & $7.1 \pm 0.6$ & $6.5 \pm 0.7$ & $0.0 \pm 0.0$ & $5.2 \pm 0.8$ & $0.8 \pm 0.3$ & $2.5 \pm 0.8$ & $2.0 \pm 0.6$ \\
\hline
\end{tabular}

Eday and Faray mice do not differ when behaviour in open-field conditions (Eday: $n=10$, Ia $=0.75 \pm 0.06$; Faray: $n=10$, Ia $=0.68 \pm 0.08$ ), or behaviour during inter-sex encounters (a two factors MANOVA on 3 and on 4 behavioural categories; Table 3 ) are considered. The only significant difference is due to a more frequent display of defensive behaviour among females $(3.4 \pm 0.8)$ than among males $(0.6 \pm 0.3)$.

\section{Physiology}

Male adult mice from the 4 islands sampled at the first session present similar body and seminal vesicle weights (Table 4), suggesting a similar stage of development. However, Westray mice are characterised by significant higher ratio of testes to body weight $\left(F_{3,37}=5.01, p=0.005\right)$. Adults trapped in August in Eday present small seminal vesicles, however their testes are of similar size to those of mice trapped in April (Table 4).

In average, females present heavier adrenals than males but there are no significant differences between islands (Table 5). Moreover, whether reference

Table 4. Body weight and ratios of seminal vesicle and testes to body weight (mean $\pm \mathrm{SE}$ ) of mice from 5 islands of the Orkney archipelago. $n$ - number of males examined.

\begin{tabular}{|c|c|c|c|c|}
\hline Islands & $n$ & $\begin{array}{l}\text { Body weight } \\
\text { (g) }\end{array}$ & $\begin{array}{l}\text { Seminal vesicle/body } \\
\text { weight }\left(\times 10^{-3}\right)\end{array}$ & $\begin{array}{c}\text { Testes/body } \\
\text { weight }\left(\times 10^{-3}\right)\end{array}$ \\
\hline \multicolumn{5}{|c|}{ First trapping session (April) } \\
\hline Westray & 8 & $27.6 \pm 0.6$ & $5.1 \pm 0.3$ & $9.4 \pm 0.8$ \\
\hline Eday & 13 & $24.1 \pm 1.1$ & $5.9 \pm 0.4$ & $7.5 \pm 0.4$ \\
\hline Papa-Westray & 10 & $27.6 \pm 1.0$ & $5.9 \pm 0.4$ & $7.3 \pm 0.3$ \\
\hline Sanday & 10 & $26.7 \pm 1.7$ & $5.8 \pm 1.0$ & $6.8 \pm 0.4$ \\
\hline \multicolumn{5}{|c|}{ Second trapping session (August) } \\
\hline Eday & 7 & $21.6 \pm 1.6$ & $3.5 \pm 0.3$ & $6.4 \pm 0.3$ \\
\hline Faray & 5 & $23.9 \pm 1.4$ & $4.6 \pm 0.6$ & $6.2 \pm 0.4$ \\
\hline
\end{tabular}


Table 5. Body and adrenal gland weights (mean $\pm \mathrm{SE}$ ) of adult mice from 5 islands of the Orkney archipelago.

\begin{tabular}{|c|c|c|c|c|c|c|}
\hline \multirow{2}{*}{ Islands } & \multicolumn{2}{|c|}{ Sample size } & \multicolumn{2}{|c|}{ Body weight (g) } & \multicolumn{2}{|c|}{ Adrenal weight (mg) } \\
\hline & Males & Females & Males & Females & Males & Females \\
\hline \multicolumn{7}{|c|}{ First trapping session (April) } \\
\hline Westray & 6 & 6 & $27.4 \pm 0.9$ & $26.6 \pm 1.0$ & $4.9 \pm 0.2$ & $10.2 \pm 0.7$ \\
\hline Eday & 11 & 11 & $24.9 \pm 1.1$ & $21.9 \pm 1.1$ & $5.7 \pm 0.2$ & $8.9 \pm 0.3$ \\
\hline Papa-Westray & 9 & 9 & $27.6 \pm 1.2$ & $26.3 \pm 0.9$ & $6.6 \pm 0.2$ & $11.0 \pm 0.8$ \\
\hline Sanday & 10 & 10 & $26.7 \pm 1.7$ & $25.2 \pm 0.9$ & $5.6 \pm 0.3$ & $8.7 \pm 0.6$ \\
\hline \multicolumn{7}{|c|}{ Second trapping session (August) } \\
\hline Eday & 5 & 10 & $22.5 \pm 3.2$ & $18.4 \pm 1.6$ & $5.7 \pm 0.3$ & $7.9 \pm 0.2$ \\
\hline Faray & 5 & 8 & $21.6 \pm 1.6$ & $20.6 \pm 1.1$ & $5.3 \pm 0.3$ & $9.5 \pm 0.5$ \\
\hline
\end{tabular}

levels of corticosterone or levels following any of the behavioural tests are considered, no sex differences were detected except for Westray mice (Table 6).

Mice from Westray and Papa-Westray present the highest reference levels when the four islands are compared. Levels of corticosterone in the plasma tend to increase following the open-field test, but this trend is only significant in the case of Eday and for Westray females (Table 6; Treatment effect: Westray, $F_{1,24}=10.23$, $p=0.004 ;$ Eday, $\left.F_{1,37}=11.80, p=0.001\right)$.

Table 6. Variation of corticosterone concentration (mean $\pm \mathrm{SE}$ ) in mice from different islands of the Orkney archipelago subjected to 4 different experimental conditions. $*$ Only case where sex differences are detected. [1] 2-way ANOVA: island, $F_{3,57}=29.10, p=0.0001$; multiple comparison of means, post-hoc test: Sanday/Westray, $p=0.0003$; Sanday/Papa-Westray, $p=0.0001$; Eday/Westray, $p=0.0002$; Eday/Papa-Westray, $p=0.00001$; sex, $F_{1,57}=0.34, p>0.05$; sex $\times$ island, $F_{3,57}=1.56$, $p>0.05$ ). [2] 2-way ANOVA: island, $F_{1,15}=0.65, p>0.05$; $\operatorname{sex}, F_{1,15}=3.81, p>0.05$; island $\times$ sex, $F_{1,15}=2.40, p>0.05$. Sample sizes are given in parentheses.

\begin{tabular}{|c|c|c|c|c|}
\hline \multirow{2}{*}{ Islands } & \multicolumn{4}{|c|}{ Levels of corticosterone ( $\mu \mathrm{g} / 100 \mathrm{ml})$} \\
\hline & Reference & Open-field & Intra-sex & Inter-sex \\
\hline \multicolumn{5}{|c|}{ [1] First trapping session (April) } \\
\hline \multicolumn{5}{|l|}{ Westray* } \\
\hline Males & $80.4 \pm 4.8$ & $92.0 \pm 9.9(10)$ & $101.8 \pm 4.0(10)$ & $95.5 \pm 18.0$ \\
\hline Females & $55.2 \pm 10.3 \quad(6)$ & $115.8 \pm 16.1$ & $106.9 \pm 10.6$ & $145.2 \pm 22.1$ \\
\hline Eday & $28.2 \pm 3.3(19)$ & $65.8 \pm 9.4(22)$ & $43.8 \pm 7.5(29)$ & $20.2 \pm 3.1(21)$ \\
\hline Papa-Westray & $84.5 \pm 6.3(20)$ & $96.6 \pm 6.2(19)$ & $28.0 \pm 6.0(20)$ & $19.9 \pm 3.3(10)$ \\
\hline Sanday & $27.1 \pm 5.7(14)$ & $27.3 \pm 10.4(10)$ & $35.1 \pm 7.0(16)$ & $58.7 \pm 17.5$ \\
\hline \multicolumn{5}{|c|}{$[2]$ Second trapping session (August) } \\
\hline Eday & $19.3 \pm 6.8(10)$ & $28.2 \pm 5.4(10)$ & none & $36.9 \pm 7.7(10)$ \\
\hline Faray & $13.7 \pm 8.7$ & $28.6 \pm 3.1(10)$ & none & $34.6 \pm 5.4(10)$ \\
\hline
\end{tabular}


Corticosterone levels following dyadic encounters differ significantly from reference levels but show a different pattern of variation in the 4 islands. A 3-way ANOVA with island, sex and treatment (reference, intra-sex, inter-sex encounters) as factors reveals significant differences between islands $\left(F_{3,184}=20.90, p=0.0001\right)$ and a significant interaction effect among island and treatment $\left(F_{6,184}=6.10\right.$, $p=0.0001$ ). Post-hoc tests show that island differences are due to significantly higher levels of corticosterone in Westray than in the other 3 islands (Tabe 6). In order to interpret the interactive effect of island and treatment, 2-way ANOVAs were performed on each island separately. In Eday and Sanday the differences observed were not statistically different. In Papa-Westray reference levels were significantly higher than levels following dyadic encounters (Treatment effect: $F_{2,44}=22.40, p=0.0001$; post-hoc Scheffé test: reference/intra-sex $p=0.0001$; reference/inter-sex $p=0.0001$ ).

In the case of Westray treatment and sex interact significantly $\left(F_{2,34}=4.93\right.$, $p=0.013$ ). Actually, reference levels of corticosterone are significantly lower than levels following intra-sex and inter-sex dyadic encounters $\left(F_{2,34}=8.80, p=0.0008\right.$; post-hoc: reference/intra-sex $p=0.004$; reference/inter-sex $p=0.003$ ), but this difference is mainly due to the females ( $T$-test: $p=0.0008$ and $p=0.0001$; Table 6 ).

\section{Discussion}

\section{Chromosomal variation and behaviour}

Behavioural traits in open-field conditions show the largest differences between populations from two islands carrying standard mice (Sanday, Papa-Westray). During dyadic encounters, frequency of non-social passive behaviour cluster Westray and Papa-Westray (Robertsonian and standard populations of mice) in one group, and Eday and Sanday in the other (also Robertsonian and standard populations). Moreover, the physiological traits measured in this study do not distinguish between populations according to their karyotypes. The obvious conclusion at that point is that chromosomal divergence does not seem to have influenced the behavioural and physiological traits measured in this study.

\section{Habitat differences and behaviour}

Faray and Eday islands carry mice with similar karyotypes but presenting different ways of life: in Faray, house mice occur in the field and feed on natural food; in Eday, house mice occur in farms and cereal ricks but not in the field.

House mice seem to survive well in the field in Faray as pregnancy rate is similar to that found in islands where the species occurs as a commensal. Population size is also higher on Faray than on Eday.

In a previous study, with other populations of mice, it was reported that outdoor mice presented a higher amplitude of response to a novelty stress than commensal 
mice (Ganem 1991). In the case of Faray mice, life in the field does not seem to have affected their physiological response to emotional stress, assessed from their plasma concentration of corticosterone following open-field and dyadic encounters. Still, when commensal and outdoor populations present similar demographical traits, their stress response may converge (Ganem 1991). This could explain the similar stress response of Faray and Eday mice. Moreover, behavioural differences between commensal and outdoor populations have been described particularly when their demographical traits were different (high density and low sex-ratio in the commensal and the opposite in the outdoor population; Bronson 1979). In the present study, the feral population of Faray presents several 'commensal traits': high population size and low sex-ratio. Thus, Faray population may have still retained characteristics of commensal mice, or the results reported in this study may correspond to a phase when outdoor and commensal mice tend to converge in some of their traits. A comparative study at another season may help to clarify this point.

\section{Comparing island-populations}

Mice from Papa-Westray present a high index of active behaviour in open-field. High activity or exploration is generally considered to indicate low emotionality (Candland and Nagy 1969), however levels of corticosterone presented by these mice at the end of the experiment suggest that stress may occur. Still, these levels of hormone are similar to those obtained in resting conditions which may indicate that these mice are caracterised by a high hormonal reactivity, and although exploratory behaviour can be considered as a 'consummatory' behaviour (Levine et al. 1979), apparently, its duration is not sufficient to reduce corticosterone levels.

Mice from Papa-Westray are also characterised by a frequent display of social investigation during dyadic encounters, and rarely show avoidance behaviour. Levels of corticosterone in the same mice is significantly lower following 10 minutes dyadic encounters than they are after the open-field tests or in standard conditions. Considering corticosterone as an index of stress sensitivity (Andrews and Belknap 1979, Ganem 1991), spatial novelty appears as more stressful for Papa-Westray mice than a dyadic encounter with a foreign mouse from the same island. The latter result is consistent with the amicable behaviour displayed by those mice during dyadic encounters.

One might be tempted to link the social amicability of mice from Papa-Westray to the fact that they were collected in a cereal rick and probably are more closely related to each other than mice trapped in different farms (Archer 1968, Hurst and Barnard 1992, but see Van Zegeren and Van Oortmerssen 1981). However, this is probably not the only reason for the pattern observed in Papa-Westray. Indeed, mice were collected in cereal ricks in Sanday as well, and these mice do not show particular social tolerance.

Sanday mice are characterised by the lowest index of active behaviour in open-field conditions, and at the same time present the lowest levels of cortico- 
sterone following this test. This is an example where in contrary to usual findings, freezing (immobility) during the open-field test do not correlate with a physiological stress. Moreover, Sanday mice present a high frequency of male aggressive behaviour during inter-sex encounters, which may indicate that a slightly different social structure may occur in Sanday compared to the other islands.

In contrary to Papa-Westray, spatial novelty (open-field) seems to be less stressful for Sanday mice than are pairwise encounters. Particularly, inter-sex encounters resulted in the highest corticosterone levels in Sanday mice, but this may be attributed to the unusual agonistic nature of that behavioural interaction (Haller et al. 1995).

Similarly to Sanday, Eday mice are characterised by low reference levels of corticosterone, but, differently from Sanday and similarly to Papa-Westray, their levels of corticosterone are higher after open-field tests than they are following dyadic encounters. The later result may be due to a novelty stress as a result of the open-field test, a stress which would diminish during the dyadic interaction as a result of habituation. The fact that Eday mice present higher levels of corticosterone after intra-sex encounters than after inter-sex encounters could also result from the fact that intra-sex encounters are perceived as less stressful than inter-sex encounters, which is consistent with a reduction in the frequency of agonistic behaviour during these encounters.

As far as corticosterone is concerned, Westray mice are the only for which sexual variations were detected. Males from this island present high reference levels of corticosterone which remain high during the three behavioural experiments. Females also present relatively high reference levels of corticosterone, however, this increases significantly during open-field and dyadic encounters. Sex differences in the hormonal response, observed in Westray, suggest a different sensitivity to behavioural challenges of males and females in this island. Males from Westray present high levels of corticosterone following the 3 behavioural tests suggesting a high reactivity of these mice.

High levels of corticosterone may be costly to an organism since chronic elevated levels of this hormone can produce kidney diseases, stomac tumors and reproduction failures (Bronson 1967, McDonald et al. 1981, Bradley et al. 1988). If chronic levels of corticosterone occurred in Westray mice, one would have expected these mice to have heavy adrenals (Christian and Davis 1956). However, this does not seem to be the case, as adrenal weight of Westray mice is similar to that of mice from the other islands and even tend to be lighter. Moreover, the data presented here concerning density, reproduction and general condition in the Westray population of mice do not indicate that this population is declining as it could have been expected considering their high reactivity (but see Boonstra and Boag 1992). The high reactivity of Westray mice may indicate a high capacity of response to novelty which could help to better cope with stress. However, and although the hypothesis would need further investigation, levels of corticosterone either do not remain chronically high and return quickly to basal levels in field 
conditions, or Westray mice present particular adaptations (eg a high corticosterone turn over rate), allowing them to maintain high levels of corticosterone without being handicapped.

Males from Westray have heavier testes than males from the other islands although they have similar body and seminal vesicle weights. Relatively large testes would be expected in populations where there is substantial sperm competition, ie a promiscuous mating system (Kenagy and Trombulak 1986, Gomendio and Roldan 1993). As, in general, the quantity of sperms that a male can produce is correlated with testis size, a greater volume of sperm could increase a male reproductive success (Ginsberg and Huck 1989). If this is true, Westray males could have a reproductive advantage on males from the other islands.

To conclude, as far as island differentiation is concerned, and given that for most islands our sampling is representative of the entire island, results obtained in this study suggest that isolation between the islands has favoured some divergence, that this divergence is not directly linked to karyotype or habitat, and, except for Eday and Faray, follows a different pattern depending on the island considered. Moreover, unless local conditions changed dramatically in the islands where the house mouse is commensal, differences between islands are expected to be consistent through time, and this idea holds particularly well when considering the differences displayed by mice in Papa-Westray as compared to Sanday while the two populations carry the same karyotype and live in nearly identical habitats.

\section{Hypotheses on the evolution of karyotypes in Orkney}

In the middle of the 19th century house mice were described as common everywhere in Orkney. This was coincident with the flourishing period of agriculture and farming (Berry 1985). One can expect that habitat saturation by mice of the different islands has occurred at this time, and that since then, knowing that once a commensal habitat is saturated a immigrant would have lower chances to establish (Van Zegeren 1980), migration between islands has been limited. This would explain divergence between very close islands characterised by apparently similar ecological conditions.

The similarities between Eday and Faray may be related to the fact that until 1947 communication between the two islands were more frequent than between any other islands because of both, their proximity, and the geographical position and small size of Faray, making the island dependent of Eday for school and shops as well as for communication via large boats with other islands and the mainland. The fact that one of the 3 fusions, which are shared by the two islands, segregates in Faray strongly suggest that part of the chromosomal evolution may be very recent, and that the non-availability of commensal habitat in Faray, and the resulting dispersal of the population, might have prevented fixation of that chromosomal mutation. There could be two other alternatives to the latter 
hypothesis. The first would be that recent introduction of standard mice took place in Faray, still, one would expect that other fusions would be segregating as well as the 4.10; moreover, migrants from the two nearby Robertsonian islands (Eday and Westray) would seem to be better candidates to such a scenario than a standard mouse. The second alternative to our hypothesis is that the segregation of fusion 4.10 would be due to fission events; however, according to recent telomeric sequence data, fission events would be very unlikely in house mice (Nanda et al. 1995).

In Orkney, the flourishing period of agriculture is over, and particularly in the smallest islands, farming tends to decrease and consequently suitable habitats for the house mouse. For example the reduction of the number of farmers on Eday (less than 120 inhabitants), the small size of the house mouse population, in addition to the fact that mice from Eday present a heavy parasite load (Ressouche et al., in press) suggest that the Rb population of Eday may be very vulnerable to extinction or/and colonisation from neighbouring islands. Observations made in Faray indicate that the house mouse can survive outdoors in Orkney. However the presence of competitors such as A. sylvaticus in Eday, and the poor competitive ability of the house mouse (Berry 1986) suggest that the house mouse may not survive in Eday if commensal habitat ceased to be available.

Farming in Papa-Westray is also declining with human population size (less than 100). In Sanday, farming is declining even though the human population size is still relatively high (around 500). Westray is one of the surviving agriculturally-based islands (more than 700 inhabitants) and carries a large and healthy' population of $\mathrm{Rb}$ mice.

Considering the evolution of human activity in the 5 islands studied and the characteristics of their mouse populations, predictions may be made concerning the future distribution of Robertsonian mice in Orkney. Unsaturation of potentially suitable habitats for the house mouse, may facilitate colonisation from nearby islands. Faray may keep its present chromosomal type with the possbility of loosing fusion 4.10 (see Berry et al. 1992), still, the risk of extinction during particularly cold years may be substantial. The characteristics of the island of Westray will probably secure the permanence of a Robertsonian population in Orkney from which colonisers may originate.

The results presented here suggest that the present pattern of karyotype variation in Orkney could change due to changes in human behaviour and demography and their consequences on commensal populations of mice. Further studies should investigate behavioural discrimination and mate choice between mice from different islands, on the one hand, and on the other, analyse dispersal and passive transport of mice between these islands. These two fields of research should provide information on whether habitat saturation is the main cause of non-mixing between the islands or whether isolation involves divergence in recognition signals between mice of the different islands and/or to the act that mice in Orkney have a low propensity for dispersal and passive transport. 
Acknowledgements: This work was supported by the French Foreign Ministry (bourse Lavoisier). It was realised during a post-doctorate stay in the Department of Zoology of the University of Oxford (U-K). I wish to thank Professor R. J. Berry and Dr J. B. Searle for their help and valuable advice, J. F. Ritz for helping with the figures, and 3 annonymus referees. Special thanks to the Hewisons of Westray and Eday. The study would not have been possible without the generosity of Orkney inhabitants. This is contribution $n^{\circ} 97-$ III of Institut des Sciences de l'évolution.

\section{References}

Adolph S. and Klein J. 1981. Robertsonian variation in Mus musculus from central Europe, Spain, and Scotland. Journal of Heredity 72: 219-221.

Andrews R. V. and Belknap R. W. 1979. Deer mouse and lemming adrenal and pathological responses to increases in animal numbers. Comparative Biochemistry \& Physiology 63A: 15-18.

Archer J. 1968. The effect of strange male odor on aggressive behavior in male mice. Journal of Mammalogy 49: 572-575.

Auffray J.-C. 1993. Chromosomal divergence in house mice in the light of palaeontology: a colonization related event? Quaternary International 19: 21-25.

Bauchau V. 1990. Phylogenetic analysis of the distribution of chromosomal races of Mus musculus domesticus Rutty in Europe. Biological Journal of the Linnean Society 41: 171-192.

Berry R. J. 1985. The natural history of Orkney. William Collins Sons \& Co. Ltd., Glasgow: 1-304.

Berry R. J. 1986. Genetical processes in wild mouse populations. Past myth and present knowledge. Current Topics in Microbiology and Immunology 127: 86-94.

Berry R. J., Berry A. J., Anderson T. J. C. and Scriven P. 1992. The house mice of Faray, Orkney. Journal of Zoobgy, London 228: 233-246.

Boonstra R. and Boag P. T. 1992. Spring declines in Microtus pennsylvanicus and the role of steroid hormones. Joumal of Animal Ecology 61: 339-352.

Bradley A. J., Kenper C. M., Kitchener D. J., Humphreys W. F., How R. A. and Schmitt L. H. 1988. Population ecology and physiology of the common rock rat, Zyzomys argurus (Rodentia: Muridae) in tropical northwestern Australia. Journal of Mammalogy 69: 749-764.

Bronson F. H. 1967. Effects of social stimulation on adrenal and reproductive physiology of rodents. [In: Husbandry of laboratory animals. M. L. Conalty, ed]. Academic Press, New York: 513-542.

Bronson F. H. 1979. The reproductive ecology of the house mouse. Quarterly Review of Biology 54: 265-299.

Candland D. K. and Nagy Z. M. 1969. The open-field: some comparative data. Annales of the New-York Acacemy of Science 159: 831-851.

Christian J. J. and Davis D. E. 1956. The relationship between adrenal weight and population status of urban norway rats. Journal of Mammalogy 37: 475-486.

Davis S. 1983. Mo:phometric variation of populations of house mice Mus domesticus in Britain and Faroe. Journal of Zoology, London 199: 521-534.

Gagnon J., Roth J. M., Finzer W. F., Hofmann R., Haycock K. A., Feldman D. S. and Simpson J. 1989. Super Anova: accessible general linear modelling. Abacus Concepts, Inc., Berkley, California: $1-314$.

Ganem G. 1991. A comparative study of different populations of Mus musculus domesticus: Emotivity as an index of adaptation to commensalism. Comparative Biochemistry \& Physiology 99A: 531-536.

Ganem G. and Sea-le J. B. 1996a. Behavioural discrimination among chromosomal races of the house mouse (Mus misculus domesticus). Journal of Evolutionary Biology 9: 817-831.

Ganem G. and Searle J. B. 1996b. Corticosterone and inter chromosomal race discrimination in the house mouse. Formones and Behavior 30: 69-73.

Genetsch C., Lichtsteiner M. and Ferr H. 1988. Genetic and environmental influences on behavioral and neurochemical aspects of emotionality in rats. Experientia 44: 482-490. 
Ginsberg J. R. and Huck U. W. 1989. Sperm competition in mammals. Trends in Ecology and Evolution 4: 74-79.

Gomendio M. and Roldan E. R. S. 1993. Mechanisms of sperm competition: linking physiology and behavioural ecology. Trends in Ecology and Evolution 8: 95-100.

Haller J., Barna I. and Baranyi M. 1995. Hormonal and metabolic responses during psychosocial stimulation in aggressive and nonaggressive rats. Psychoneuroendocrinology 20: 65-74.

Hurst J. L. 1993. The priming effects of urine substrate marks on interactions between male house mice, Mus musculus domesticus Schwarz \& Schwarz. Animal Behaviour 45: 55-81.

Hurst J. L. and Barnard C. J. 1992. Kinship and social behavior in wild house mice: effects of soocial group membership and relatedness on the responses of dominant males toward juvenils Behavioural Ecology 3: 196-206.

Kenagy G. J. and Trombulak S. C. 1986. Size and function of mammalian testes in relation to body size. Journal of Mammalogy 67: 1-22.

Levine S., Weinberg J. and Brett L. P. 1979. Inhibition of pituitary-adrenal activity as a consequence of consummatory behavior. Psychoneuroendocrinology 4: 275-286.

Mackintosh J. H. 1981. Behaviour of the house mouse. Symposium of the Zoological Society of London 47: $337-365$

McDonald I. R., Lee A. K., Bradley J. and Than K. A. 1981. Endocrine changes in dasyurid marsupials with differing mortality patterns. General Comparative Endocrinology 44: 292-301.

Nachman M. W., Boyer S. N., Searle J. B. and Aquadro C. F. 1994. Mitochondrial DNA variation and the evolution of Robertsonian chromosomal races of house mice, Mus domesticus. Genetics 136 1105-1120.

Nanda I., Schneider-Rasp S., Winking H. and Schmidt M. 1995. Loss of telomeric sites in the chromosomes of Mus musculus domesticus (Rodentia: Muridae) during Robertsonian rearrangements. Chromosome Research 3: 399-409.

Nash H. R., Brooker P. C. and Davis J. M. 1983. The robertsonian translocation house-mouse populations of North East Scotland: a study of their origin and evolution. Heredity 50: 303-310.

Pelikan J. 1981. Patterns of reproduction in the house mouse. Symposium of the Zoological Society of London 47: 205-224.

Pfister H. P. 1979. The glucocorticosterone response to novelty as a psychological stressor. Physiology and Behavior 17: 43-46.

Ressouche L., Ganem G., Derothe J.-M., Searle J. B., Renaud F. and Moulia C. (in press). Host chromosomal evolution and parasites of the house mouse Mus musculus domesticus in Scotland. Zeitschrift für Säugetierkunde.

Scheffé H. 1959. The analysis of variance. John Wiley \& Sons, Inc., New York: 1-477.

Schuhr B. 1987. Social structure and plasma corticosterone level in female albino mice. Physiology and Behavior 40: 689-693.

Searle J. B., Narain Navarro Y. and Ganem G. 1993. Further studies of a staggered hybrid zone in Mus musculus domesticus (the house mouse). Heredity 71: 523-531.

Van Zegeren K. 1980. Variation in aggressiveness and the regulation of numbers in house mouse populations. Netherlands Journal of Zoology 30: 635-770.

Van Zegeren K. and Van Oortmerssen G. A. 1981. Frontier disputes between the West and East-European house mouse in Schleswig-Holstein, West Germany. Zeitschrift für Säugetierkunde 46: 363-369.

Received 15 February 1996, accepted 4 September 1997. 